UNITED STATES

DEPARTMENT OF THE INTERIOR

GEOLOGICAL SURVEY

\title{
REPORT ON THE ENVIRONMENTAL GEOLOGY \\ OCS AREA. EASTERN GULF OF ALASKA
}
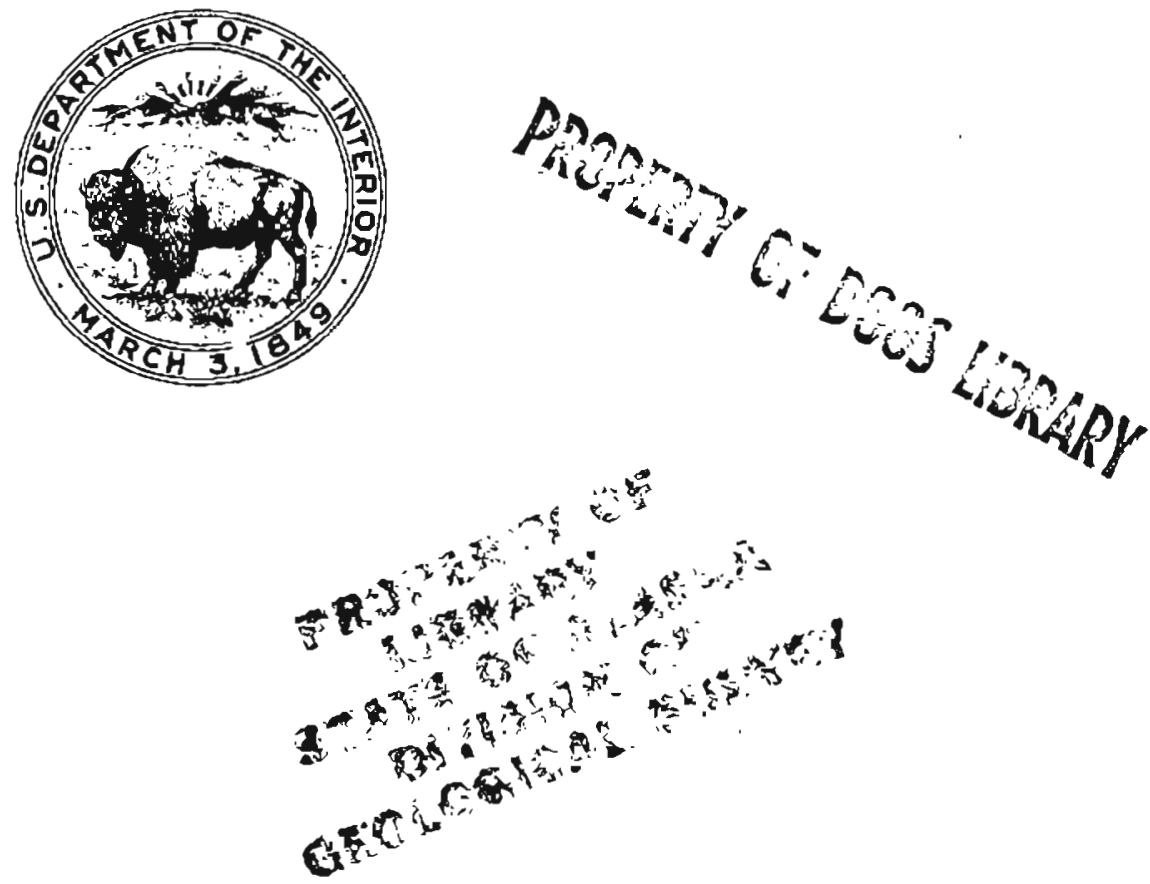

OPEN-FILE REPORT 76-206

This report is preliminary and has not been edited or reviewed for conformity with Geological Survey standards and nomenclature

Menlo Park, California

March 1976 


\section{UNITED STATES \\ DEPARTMENT OF THE INTERIOR \\ GEOLOGICAL SURVEY}

\section{REPORT ON THE ENVIRONMENTAL GEOLOGY}

OCS AREA, EASTERN GULF OF ALASKA

By

Bruce F. Molnia, Paul R. Cazkson, and Terry R. Bruns

OPEN-FILE REPORT 76-206

This report is preliminary and has not

been edited or revlewed for conformity

with Geological Survey standards and

nomenclature

Menlo Park, Califomia

March 1976 


\section{U.S. GEOLOGICAL SURVEY \\ Reston, Vo. 22092}

Memorandum

To: Branch of Plans and Program Managcment, Publications Division - Stop 329

From: Chicf, office of Sclentific Publications

Subject: New USGS open-file report

The following report was authorized by K. P. Ketterer for the Director on $2 / 23 / 76$ for release in the open files:

TITES Report on the environmental geology, OCS area, eastern - Gulf of Alaska

AUTHDR(9)\& Bruce F. Molnia, Paul R. Carlson, and Terry R. Bruns

conteriss:

28 p.,

plo.,

18 flga., tablos.

Plap acalos

\section{Depositories:}

USGS Library, Room 4A100, 12201 Sunrise Valley Dr., Reston, VA 22092

USCS Library, Stop 914, Box 25046, Federal Center, Denver, C0 80225

* USGS Library, 345 Middlefield Rd., Menlo Park, CA 94025

USGS, Natural Resources Bldg., College, AK 99701

USGS, Room 441, Federal Bldg., Juneau, AK 99801

* USGS, Room 108, Skyline Bldg., 508 2nd Ave., Anchorage, AK 99501

- USOS, Roon 678, U.S. Court House, West 920 Riverside Ave., Spokane, lia 99?01 LSGS, Room 504, Custor House, 555 Battery St., San Francisco, CA 94111

.USGS, Room 7638, Federal Bldg., 300 North los Angeles St., Los Angeles, CA 90012 USGS, Room 1012, Federal Bldg., 1961 Stnut St., Denver, Co 80202

Alaska Div. Geol: and Geophys. Surveys, Room 509, Goldstein Bldg., Juneau, AK -99801 Alaska Div. Geol. and Geophys. Surveys, 323 East 4 th Ave:, Anchorage, AK 99504 Alaska Div. Geol. and Geoplys. Surveys, University Ave., College, AK 99701

(R)

47 o

report

(a) $12-$

cast approx $\$ 15.58$

plus paitage

Release date: MARCH 1976

Area:

ALASKA

(4) Asterisks indicate depositories Repart No.

76-206 holding reproducibles. 


\section{CONTENTS}

I. Introduction. .............................

II. Surface Sedimentary Units by

Bruce $F$. Molnia and Paul $R$. Carlson....................4

III. Clay Mineralogy of sediment Samples by

Bruce $\mathrm{F}$. Molnia and Paul T. Fuller................... 9

IV. Benthonic Foraminifera and Calcareous Nannoplankton by

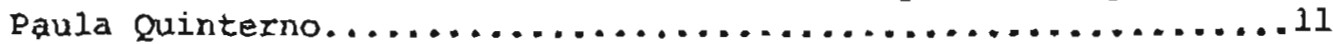

V. Subrarine Faults and Slides by

Paul R. Carlson, Terry R. Bruns, and Bruce F. Molnia.........15

VI. Geologic Structure by

Terry R. Bruns and George Plakfer......................

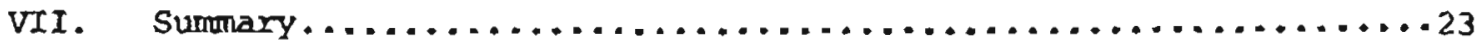




\section{INTRODUCTION}

In anticipation of oil and gas leasing of the outer continental shelf (ocs lease area 39) in the northeastern Gulf of Alaska, the U. S. Geological Survey began a regional reconnaissance in 1974. The study area, which extends from Prince william sound on the west to Yakutat Bay on the east, is in a region fraught with natural hazards. The tectonic history of the area suggests that future major earthquakes could pose serious hazards to installations on the continental shelf or along the coast of the Gulf of Alaska. The hazard may be either direct, by ground shaking or fault displacement, or indirect, through ground failure or generation of tsunami waves. Storm waves sometimes are responsible for ground failures, especially in areas of rapid accumulation of sediment.

Because of the paucity of non-proprietaxy marine geological and geophysical data, the U. S. Geological survey operated a cruise in the northern Gulf of Alaska OCS axea (fig. 1) in September and October 1974 aboard the University of Washington's R/V Thomas G. Thompson. Data collected include three types of continuous acoustic profiles; energy sources were a $3.5 \mathrm{kHz}$ transducer, two minisparkers (800 Joules) and two 40 in. $^{3}$ aix guns. Two later cruises aboard NOAA ships, Surveyor (April - May 1975) and FRS Townsend Cromwell (May - June 1975) added more high resolution seismic data and approximately 425 sediment samples. In all, more than $12,000 \mathrm{~km}$ of high resolution seismic data were collected within the study area. Several types of navigation equipment were used 
because of intermittent power and equipment failures; the instruments included Decca Hi Fix, Satellite, Loran A Radar, and Radist.

The seismic reflection data from the Thompson cruise have been released in an open-file report (von Huene and others, 1975), which is available to the public. The remaining data are being prepared for open-Eile report.

The locations of the Thompson tracklines are shown on figure 2, the Surveyor tracklines on figure 3 , and the Cromwell sediment samples on figure 4. Figure 1 is a base map compiled from Thompson and 1972 Surveyor data.

This report is a synthesis of our preliminary evaluations of sediment types, distributions (both areally and stratigraphically) and thicknesses, sea floor hazards (slumps and faults) and geologic structure.

The following people wero very helpful to the usGs project during FY 75. We would l1ke to acknowledge their assistance:

Shipboard Assistance

R. V. Thompson

X. Bayer

D. Bernhardt

J. Bragg

B. Chiodo

J. Grow

N. Harden

J. Hendricks

M. Henry

M. Holmes

B. Mattick

w. McCauley

K. McKelvy

H. McLean

R. Patrick

J. Raemy

E. Reimnitz

X. von Bock

R. von Huene
Surveyor

K. Bayer

D. Cavit

R. Cruickshank

S. Davenport

P. Fuller

A. Hickling

S. Johnson

J. Joyce

J. Nicholson

M. Randall

H. Smith

G. Tanner

D. VanNieuwenhulse

F. Wahl

S. Wallace

L. Wright

J. Yarus
Cromwe 11

J. Curtis

N. Harden

G. Luepke

A. 5tephenson

G. Tanner

S. Wallace

G. Winklex 
Lab Assistance

D. Condra

R. Cxuickshank

J. Curtis

P.. Fuller

J. Hampson

S. Kittleson

P. Shryock

P. Smith

L. Wright 


\title{
II. SUREACE SEDIMENTARY UNITS
}

by

\author{
Bruce F. Molnia and Paul R. Carlson \\ Description of Sedimentary Units
}

Four major sedimentary units occur on the continental shelf of the northern Gulf of Alaska (fig. 5). These units, which are characterized by their"seismic signatures", are: (1) Holocene sediments (fig. 6), (2) Holocene end moraines (fig. 7), (3) Quaternary glacial marine sediments (fig. 8) and (4) Tertiary and Pleistocene strata (fig. 9). The ages assigned to these units are based on their relative stratigraphic positions. The term "Holocene" is applied to sediment accumulating today and to end moraines formed during historic time. The most widespread of these two Holocene units is largely clayey silt and appears on seismic profiles as relatively horizontal, parallel reflectors (fig. 6), except where disrupted locally by slides and slumps (Carlson and others, 1975). The second Holocene unit appears as a jumbled mass of irregular reflectors representing recent end moraines off the Malaspina and Bering Glaciers (fig. 7).

Holocene sediments are underlain locally by a glacial marine unit of pebbly mud which is characterized on the seismic profiles by very irregular, contorted reflectors (fig. 8). This unit is assigned a Quaternary age because of its stratigraphic position between Holocene sediments and rertiary to Pleistocene rocks. Elsewhere this glacial marine unit is absent and the 
Holocene deposits overlie folded, faulted and truncated strata of probable Tertiary or Pleistocene age (Eig. 9). This age assignment is based on similarities in lithology and structure of these rocks to onshore lithified strata which have been dated as Tertiary and Pleistocene (Plakker, 1967).

\section{Distribution of Sedimentary Units}

Holocene sediments blanket the near shore area between Hinchinbrook Island and the south end of Kayak Island. These deposits are thickest southeast of the main channel of the copper River, where fine sands and clayey silts of the Copper River prodelta are $350 \mathrm{~m}$ thick (fig. 10). Thick sequences of sediment also are present: (1) seaward of Icy Bay near Malaspina Glacter (260 m), (2) south of the Bering Glacier (200 m), (3) betwen Hinchinbrook and sontague Island $(250 \mathrm{~m})$, and (4) at the southwest end of Kayak Trough (155 m). In addition, Holocene sediments compose the surface fill in the Hinchinbrook sea Valley and cover parts of the area between Tarr Bank and Middleton Island. Holocene sediments also blanket the near shore area east of Kayak Island except where Holocene morainal deposits are present at Icy Bay and the Bering Glacier, and where Tertiary and Pleistocene bedrock crops out southwest of Cape Yakataga between Cape Suckling and Icy Bay. Holocene sediments also occur in a series of isolated pods toward the outer edge of the continental shelf.

Holocene end moraines are found at the mouth of Icy Bay and south of the Bering Glacier (flg. 5). A portion of the Bering Glacier moraine is shown in figure 7. Morainal sediments also were collected south of the Malaspina Glacier and at the mouth of Yakutat Bay. However, 
until these deposits are better defined by seismic profiling they cannot be identified positively as end moraines.

Quaternary glacial marine sediments axe found in a narrow arc along the north and west side of Tarr Bank and in a broad arc along the outer shelf and upper slope between Kayak Island and Yakutat Bay (fig. 5). Samples of glacial marine sediment generally are composed of pebbly or sandy mud. Figure 8 is a typical seismlc profile of glacial marine sediments.

Tertiary or Pleistocene stratified sedimentary rocks, commonly Folded, faulted and truncated, crop out on the sea floor south of Montague Island and at several localities southeast and southwest of Cape Yakataga (fig. 5). Folded Plelstocene and Tertiary strata on Tarx Bank are shown in figure 9. Dart coring was attempted in many areas of submarine outcrop during the Cromwell cruise. Few samples wexe recovered, although the presence of bedrock commonly was indicated by dented core barrels.

Bedrock also crops out at Seal Rocks and Wessels Reef between Cape Hinchinbrook and Middleton Island; these exposures were examined in June 1975. Seal Rocks consist of well indurated sandstone and argillite that are indistinguishable from rocks assigned to Orca Formation on Montague and Hinchinbrook Islands (Winklex, 1973). Wessels Reet is composed of friable sandstone and granule conglomerate that is similar lithologically to rocks of the Katalla-poul Creek Formation 
on Kayak Island (Plafker, 1974; Winkler, pers. commun., 1975).

Sampling on Tarx Bank revealed that large areas are covered by

a thin veneer (approximately one metre thick) of recent sediment. This veneer is not detectable on seismic profiles because of the transparency of the sediments and the limited resolution $(<2 \mathrm{~m})$ of seismic systems, and is not shown on the sediment distribution map. Sources of Holocene Sediment

The main sources of Holocene sediment are the Copper River, which supplies $107 \times 10^{6}$ metric tons of detritus annually (Reimnitz 1966), and the Bering and Malaspina Glaciers. The sediment being supplied by the two large piedmont glaciers is primarily suspended matter the resultant plumes are easily visible more than $30 \mathrm{~km}$ from shore on satellite tmagery (Reimnitz and Carlson, 1974). A secondary but significant source is the Copper River Plateau and Delta; fine sediment is carried by strong north winds which in fall and winter are funneled through the Copper River Gorge with sufficient force to carry dark clouds of silt over $50 \mathrm{~km}$ into the northern Gulf of Alaska (Carlson and others, in press).

The sediment, whether supplied by river, glacial runoff, or wind, is exposed to near shore currents which, with the exception of local eddies, move in a counterclockwise direction as does the offshore Alaska Current (Reimnitz and Carlson, 1974). The counterclockwise movement transports the suspended sediment west. Much Copper River sediment is carried into Prince William Sound through passes east and west of Hinchinbrook Is land. Sediments which are part of the Bering Glacler runoff plume axe transported around Kayak Island; satellite imagery showg complex gyres of turbid water on both sldes of the island 
(Reimnitz and Carlson, 1974). Some suspended sediment probably settles out over Kayak Trough. However, high-resolution seismlc profiles indicate that very little suspended matter either from the Copper River or from sources east of Kayak Island accumulates on Tarr Bank or on the Middleton Island platform. The lack of sediment cover on these topographic highs may result from scouring action of rapid bottom currents and from the frequent storm waves that are particularly laxge and forceful during the winter season of intense low pressure activity in the Gulf of Alaska. 


\title{
III. Clay Minexalogy of Sediment Samples
}

By

Bruce F. Molnia and Paul T. Fullex

\begin{abstract}
Nineteen selected sediment samples (fig. 11) collected during the June 1975 cruise of FRS Cromwell were processed and analyzed to determine their clay mineralogy. Individual minerals were identified x-raying Mg-saturated $<2 \mu$ clay separates with a Norelco diffractometer. The quantity of each clay mineral was estimated using the peak-area technique described by Hein, Scholl and Gutmacher (in press). Chlorite is the predominant clay mineral, averaging 52.68 ; illite averages $37.88 ;$ kaolinite 9.28 and montmorillonite 0.68 . No other clays were detected. Quartz, feldspar and amphibole were present In the clay size fraction. The percentages of clay minexals present in each sample, are shown in the following table.
\end{abstract}


Table 1

Percentages of Clay Minexals Present

Sample

$\# 63$

\#6

$\# 148$

$\# 131$

\#296

\#243

\#350

$\# 225$

$\$ 88$

$\# 70$

\#325

\#227

\#87

$\# 81$

\#259

$\# 299$

$\# 239$

$\# 54$

\#111

Range,

al1 samples

Average,

all samples
Montmorillonite

3

3

$0-1$

$0-1$

0

0

0

0

1

0

0

0

$0-1$

$0-1$

0

0

0

0

$0-1$

$0-3$

0.6
Illite

35

36

39

37

30

35

33

33

40

56

45

35

54

37

31

35

34

39

34

$30-56$

37.8
Kaolinite

9

53

52

52

54

60

55

57

57

49

37

47

55

39

54

59

55

56

52

56

$37-60$

$7-10$

9.2

52.6 
IV. BENTHONIC FORAMINIFERA AND CALCAREOUS NANNOPLANKTON

by

Paula Quinterno

Twenty selected samples from the northeastern Gulf of Alaska (fig. 12), taken from the undisturbed upper 2 an of sediment in grab samples or box cores, were examined for Quaternary benthonic foraminifexa. Seven samples were split (using a micro splitter) to get representative specimens from the greater than $150 \mu$ fraction; approximately 350 specimens were obtained. These were counted and the relative frequency percentages of benthonic foraminiferal species were detexnined. On the basis of the percentage distributions, four faunal assemblages were distinguished. Cursory exarination of the remaining 13 samples showed that most samples could be assigned to one of these four groups. Characteristics of the faunal assemblages are as follows:

Group I (6 samples--stations $28,34,124,137,141,305)$. Cassidulina cali fornica, C. limbata and C. subglobosa dominant; Cibicides lobatulus and Angulogerina fluens present in significant numbers; foraminiferal fragments comunon; the tests of most calcareous foraminiferal specimens present are opaque; arenaceous specimens less than 108 of total.

Group II (4 samples--stations 12, 14, 59b and sample fron Resurrection Bay).

Nonionella pulchella, Globobulimina auriculata, and Nonion labradoricum dominant: specimens very well presexved; arenaceous specimens are more than $10 \%$ of total.

Group III ( 7 samples--stations 26, 38, 105, 127, 128, 225 and 258).

Approximately 30 of the specimens are arenacous and 
consist mainly of Baplophragrooldes gubglobosum, Recurvoides turbinatus, Adercotryma glomeratum and Alveolophragmium crassimargo, the calcareous foraminifera, Epistominella pacifica is present in most samples; specimens are very well preserved.

Group IV (2 samples--stations 6, 9). Uvigerina peregrina, Cassidulina teretis and C. californica dominant; arenacous specimens are moxe than 10\% of total.

Although the Group I faunal assemblage is widespread throughout the area, it occurs only at stations with the coarsest sediment. of the six samples assigned to this groups, two are sandy gravels and four are sandy or pebbly muds.

of the 13 samples with Group II, III, and IV faunal assemblages, eleven are muds and two are sandy muds. Group II and IV assemblages occur only west of Middleton Island.

Well-consolidated sediment was obtained from the bottoms of dart and gravity cores at stations 65D, 68C, 222, 230, 302C, 329, and 359B (fig. 12). Samples from these stations, as well as two samples from a beach approximately eight $\mathrm{km}$ southeast of Lituya Bay (PC-1 and PC-2) and one from Wessells Reef, were examined for pre-Quaternary calcareous nannoplankton and benthonic forarinifera. According to David Bukxy (USGS), most sampleg were barren of nannofossils; where nannofossils were present, they were quaternary or not age-diagnostic. Preliminary study of pre-Quaternary benthonic foraminifera by Weldon Rau (State of Washington and USGS) indicates a midale to outer shelf environment of deposition and a late Miocene to Pliocene age for station PC-1. The foraniniferal assemblage from station 302C, an area southwest of Yakutat Seavalley, suggests a Pliocene 
or Pleistocene age and deposition on the shelf, probably at greater than littoral depths. The fauna from station 359B, on the northwest side of Pamplona Ridge, is within the Pliocene-Plelstocene age range and is probably Pleistocene; depositional environment was probably outer to middle shelf. A sample from station 329 contains a very shallow water fauna no older than Pleistocene and probably of Holocene age. Glauconite, a green iron-rich mineral, occurs as internal casts in the tests of foraminifexa in several samples collected from the top $2 \mathrm{~cm}$ of sediment as well as from one sample (station 222) taken from the bottom of a dart core. As the formation of glauconite is favored by slow sedimentation and slightly reducing conditions, further study of the distribution of this mineral in samples from the northeastern Gulf of Alaska may provide information on depositional environments. Another topic under study is the species composition and geographic distribution of the living benthonic foraminifera. Samples from the undisturbed upper 2 an of sediment from grab samples and box cores were preserved in buffered formalin and stained with sudan Black B according to the procedure described by Walker and others (1974). Specimens that were living at the time of collection can be recognized because they contain protoplasm which will be stained a dark blue-black. As yet, no analysis have been completed. 


\section{Refexences Used for Species Identification}

Cushman, J. A., and MCCulloch, I., 1939, A report on some arenaceous foraminifera: Allan Hancock Pacific Exped., v. 6, no. 1, 113 p.

Galloway, J. J., and Wissler, S. G., 1927, Pleistocene foraminifera from the Lomita Quarry, Palos Verdes Hills, Callfornia: Jour. Paleo., *. 1, no. 1, p. 35-87.

Loeblich, A. R., Jr., and Tappan, H., 1953, Studies of Arctic foraminifera: Smlthsonian Misc. colln., v. 121, no. 7, 150 p. Todd, R., and Low, D., 1967, Recent foraminifera from the Gulf of Alaska and southeastern Alaska: U.S. Geol. Survey Prof. Paper 573-A, p. Al-A46, pl, 1-5. Uchio, T., 1960, Ecology of living benthonic foraminifera from the San Diego, California area: Cushman Found. for Foram. Research Spec- Publ. no. 5, 72 p. 


\section{Submarine Faults and slides}

by

Paul R. Carlson, Terry R. Bruns, and Bruce F. Molnia

\section{Nearsurface Faults}

Traces of near surface and surface faults (fig. 13) were interpreted largely from minisparker records (figs. 14 and 15); airgun and $3.5 \mathrm{kHz}$ records were aids. Most of the faults cut strata similar and possibly equivalent to the upper Yakataga Formation, which is middle Miocene to lower Pleistocene in age (Plafker, 1967)."These strata commonly are covered only by a thin veneer of Holocene sediment (fig. 15) and in many places they crop out at the sea floor (fig. i4). A few of the faults appear to cut Holocene sediments (fig. 15), but none were found that unequivocally offset Holocene sediment at the sea floor. The near surface faults mapped thus far occur mostly in four areas: (1) south of Cape Yakataga, (2) on or adjacent to the Kayak Island platform; (3) on Tarr Bank and (4) near Middleton Island.

\section{Recent and Potential slides and slumps}

Axeas of slumping and sliding, both real and potential, are shown on figure 13. Seismic profiles showing the disrupted bedding and irregular topographic expression commonly associated with submarine slides or slumps (figs. 16 and 17) are most prominent in two areas. The slumped section south of Icy Bay and the Malaspina Glacier has a surface area of about $1770 \mathrm{~km}^{2}$. It occurs on a very gradual slope (less than $1 / 2^{\circ}$ ) but is in an area of thick (>150m) Holocene sediment. 
A second large slumped section is present on the Copper River prodelta. This slumped section has an area of about $1730 \mathrm{~km}{ }^{2}$, and also is assoclated with gentle slopes $\left(\sim 1 / 2^{\circ}\right)$ and a thick $(>200 \mathrm{~m})$ wedge of rapidly deposited Holocene sediment. According to Morgenstern (1967), in regions with high rates of sedimentation such as deltas, the time lag between accumulation and consolidation gives rise to excess pore pressure, thus weakening the deposit; such under consolidated material is prone to slumping. The Coppex River prodelta was investigated with seismic profiling equipment by Reimnitz (1972) shortly after the 1964 Alaska earthquake. He attributed the slump structures seen on high resolution seismic records to this earthquake. These slump structures are similar in size and shape to those visible on our profiles over this same area (fig. 16).

Acoustic profiles show a massive submarine slide at the east edge of the Copper River (fig. 27). This $17 \mathrm{~km}$ long slide has a volume of about $5.9 \times 10^{11}{ }^{3}{ }^{3}$ (Carlson and Molnia, 1975a), and has moved down a slope of about one degree to the bottam of Kayak Trough. Sediment samples collected from the upper metre of this slide consist of structureless, gray clayey silt of extremely low strength (laboratory tests with a vane shear device yield a peak shear strength of $.02 \mathrm{kmg} / \mathrm{cm}^{2}$ ). Swarms of small, discontinuous scraps were found along several seismic lines at the outex edge of the continental shelf south of Rayak Island (fig. 13). Tertiary strata are disrupted at the sea floor and the relief along these numerous scarps is about $2-5 \mathrm{~m}$. These scarps may outline slump blocks at the edge of the shelf. 
Several large potential slump or slide areas are delineated on figure 13. In these areas slopes range from $1^{\circ}$ to $8^{\circ}$ and the thickness of unconsolidated sediments exceeds $25 \mathrm{~m}$. Although slump or slide features are not prominent on the seismic profiles, a strong possibility of ground failure exists if a large earthquake provides rapid ground accelerations or if a large tsunami or storm wave disrups the sea floor. Such catastrophic events were experienced by many communties in the Prince William Sound region and along the shoreline of the Gulf of Alagka during the 1964 Alaska earthquake (Grantz and others, 1964, Coulter and Migliaccio, 1966; and Plafker and others, 1969). 


\section{VI, GEOLOGIC STRUCTURE}

This chapter provides a brief preliminary interpretation of the geologic structure of a portion of the offshore Gulf of Alaska Tertiary Province between Icy Bay and Montague Island (Fig. 18). Some of the data and interpretations were presented orally at the 1975 meeting of the Pacific Section American Association of Petroleum Geologists, (Bruns and Plafker, 1975). The seismic records on which this chapter is based are publicly available in U. S. Geologic survey Open File (von Huene and others, 1975).

\section{General Setting}

The Gulf of Alaska Tertiary Province is a compound continental margin basin made up almost entirely of terrigenous clastic rocks with minor coal intercalated with subordinate mafic volcanic and volcaniclastic rocks. The topography, basin architecture, structural style, and seismotectonic activity within this province reflect the interactions that have occurred during late Cenozolc (post-oligocene) time along the interface between the North American and Pacific plates, As a consequence of these movements, the western part of the province adjacent to the Aleutian Trench and arc is essentlally a zone of compressive deformation along which the Pacific plate is underthrusting the continental margin, the easternmost part is a zone of shear in which the oceanic plate is moving laterally past the continent along the Queen Charlotte transform and related strikeslip faulta, and the central part of the province is a zone of combined compression and shear due to oblique underthrusting of the continental margin (Plafker, 1969). The structural traps for petroleum accumulation 
and the geologic hazards in the region are direct results of this unique setting in an arc-transform transition zone.

The sedimentary sequence in the province ranges in age from paleocene through Pleistocene (Plafker, 1971). It is broadly divisible into (1) a thick lower untt of well-indurated, intensely deformed deep marine to continental rocks, mainly of Paleocene and Eocene age, and (2) an upper unit, largely of bedded marine sedimentary and volcanic rocks of Oligocene through Plelstocene age, that is notably less deformed and indurated. Most indications of petroleur in the basin are in rocks of the younger sequence, which has a composite thickness of $6,000-7,600 \mathrm{~m}$. The early Tertiary sequence is too indurated and too intensely deformed to have more than modest potential for petroleum.

\section{Data Interpretation}

Interpretation of offshore structure is based mainly on the unprocessed analog single channel air gun selsmic records from the 1974 Thompson cruise, line spactngs are between 9 and $15 \mathrm{~km}$, and acougtic penetration is generally less than 2 seconds (two-way time). Interpretation is complicated by relarively shallow penetration and by persistent water bottom multiples, especially in areas of shallow dip.

Preliminary interpretation of the data indicates that offshore, the province is structurally complex and consists of several areas with markedly differing structuril styles. Complexity appears to increase from east to west. Figure 18 shows offshore structural contours and trends in the near surface, based on a highly interpretative study of the available data. For comparison, major onshore structural trends evaluated previously by Plafker (1971) are depicted. Offshore contours are in unmigrated, twoway travel time (seconds), no attempt has been made to convert to depth 
due to lack of adequate velocity control. Mapping of the horizone is based on dip projectlons, record characteristics, and the assumption that neax surface geologic horizons are relatively conformable which permits them to be projected based on the dip of overlying events. Avallable data indicate this assumption to be valid. The structural contours primarily depict shallow structure, probably within the upper part of the Yakataga Fozmation of late Miocene and younger age (Plafker, 1971). Although the configuration of the deeper basins is somewhat speculative, the shallow structural highs probably are accurately shown. Deeper structural complexities are not identified from available data. By analogy with the adjacent onshore geology, the deeper structure offshore may be considerably more complex than is indicated by the near surface structural contours.

Structural contours between Kayak Island and Icy Bay are shown on two horizons. The westexnmost horizon is structurally the deeper of the two by $3 / 4$ to 1 second. The section appears to thicken towards the shelf edge, particularly in area where the change in horizons occurs. Total section penetrated is a maximum in the area around Icy Bay and thins to the west. This interpretation is based on the truncation of seismic events at the sea floor. The total thickness of section in the basin cannot be estimated from the reflection data because of the shallow penetration. However, relatively low velacities encountered in the sedimentaxy colum on five seismic refraction lines acquired during the 1974 Thompson cruise suggest a clastic section, predominantly of sandstone 
and shale, as much as $12 \mathrm{~km}$ thlck in the eastern part of the area south of Icy Bay and at least $9 \mathrm{~km}$ thick southeast of Kayak Island (Ken Bayer, personal comunication).

Structural contours in the area between Kayak Island and Montague Island are shown on three horizons. Due to the structural complexity and lack of critical data, the relationships between these horizons cannot be adequately determined. The contoured horizon between Kayak Island and Middleton Island appears structurally deeper than the contouxed area landward of it; comparison with the area southwest of Middleton Island is not possible due to the complexity of the Midaleton Island Platform. The contours in this area are more speculative than those between Icy Bay and Kayak Island. Shoreward of the contoured areas, and in the area inmediately west of Kayak Island, acoustic basement appears to be shallow and definition of the structure is not adequate for contouring.

\section{Offishore Structural Featureg}

Between Icy Bay and Kayak Island the shelf is underlain by two types of structures. The first type is a series of asymetric linear folds that trend obliquely across the shelf, roughly between northeastsouthwest and east-west. These structures appear more open and less complex than those on the adjacent land areas. Some of the offshore anticlines are bounded on the southeast by north - dipping thrust faults along which there may have been substantlal displacement. The second type of structure is a large shelf-edge arch east of Kayak Island trending sub-parallel to the coagt and having very gentle surface dip. Between this arch and the coagt is a broad downwarp as much as $48 \mathrm{~km}$. wide within which there are some upwarped areas, A possibly similar 
arch occurs southwest of Icy Bay at the shelf edge although more data are reguired to define the structure in this area. No structure is apparent in the area between Pamplona Ridge and the shelf edge high to the west; however, weak indications of deeper structural complexity are seen on one line which extends off the shelf into deep water, The shelf between Kayak and Middleton Island is underlain by a broad zone of complex structures trending between east-west and northeast-southwest, subparallel to major on-land stxuctures and to the eastern Aleutian Trench. Structural highs tend to be asymetric and bounded by thrugt faults on thetr south or southeast limbs. Uplift, deformation and faulting are greater than on the Icy Bay structural features, and the crests of many of the highs appear to have been truncated by eroston exposing complexly deformed Tertiary rocks at or near the sea Eloor. Northwest of Middleton Island are two laxge northwest trending structural highs separated by a deep basin. These complex structures, which are divergent from the Icy Bay and Kayak-Middleton trends, show severe deformation and probably faulting on their flanks, and no structure can be resolvable within their cores. Middleton Island lies on the northwest flank of a large northeast-trending structural high and appears to be separated from the northwest trending structures by a relatively deep basin. Most of the highs between Kayak and Montague Islands are shown as closed anticlines; however, lack of definition in profileg from this area does not preclude these highs that could result from block faulting. If such were the case, the closure shown on figure 18 would not be accurate. 


\section{Summary}

Four major sedimentary units, which are characterized by their seismic signatures, occur on the sea floor of the continental shelf in the study area. They are: (1) Holocene sediments which range from sands to silty clays, (2) Holocene end moraines which consist of gravelly, sandy muds, (3) Quaternary glacial marine sediments which are primarily pebbly muds, and (4) Tertiary and pleistocene lithifled deposits, which vary from dense, well-cemented sandstones to poorly consolidated pebbly mudstones.

Holocene sediment blankets: (1) the entire near shore area between Binchinbrook Island and the south end of Kayak Island (2) most of the near shore area east of Kayak Island, (3) the gurface fill in the Hinchinbrook Sea Valley, and (4) the area south of Tarr Bark and north of Middleton Island. Holocene end moralnes are found at the mouth of Icy Bay, south of the Bering Glacier, and at the mouth of Yakutat Bay. Quaternary glacial marine sediment occurs in a narrow arc along the north and west sides of Tarr Bank and along the outer shelf and upper slope between Kayak Island and Yakatat Bay. Stratified sedimentary rocks, often folded, faulted, or truncated, crop out: (1) on Tarr Bank, (2) offshore of Montague Island, (3) in several localities southwest and southeast of Cape Yakataga, (4) on Seal Rocks, and (5) on Wessels Reef. These outcrops apparently are offshore extensions of onshore formations such as the Orca, Katalla, Poul Creek and Yakataga. The lack of Holocene cover over a shallow area so close to major sources of sediment indicates the presence of strong bottom currents which prevent deposition, and also the strong erosive capabilities of the frequent storn waves which 
perlodically scour the banks bare of sediment.

High rates of sediment accumulation seaward of the Copper River and the Bering and Malaspina Glacters are verifled by high-resolution seismic proflles which show thick sections of Holocene sediment (200$350 \mathrm{~m})$. Rapid accumulation of the glacially derived sands, silts, and clays regults. In high pore-water pressures and undexconsolidation of the sediment, creating a high potential for submarine slides of slumps even on slopes of less than one degree. Two areas, both more than $1700 \mathrm{~km}^{2}$, of thick Holocene sediment show evidence of submarine mass movement, (1) south of Icy Bay and the Malaspina Glacier, and (2) seaward of the Copper River. Several other areas have been mapped as potentially unstable because of relatively thick accumulations of Bolocene sediment on slopes greater than one degree.

Slumping is also a common feature at the shelf edge and on the continental slope. Near the shelf edge south of Kayak Island, the surficial sedimentary units (probable Tertiary age) are cut by a swarm of discontinuous step-scarps. Two scaxps have relief of 2-5 m and may delineate slump blocks at the edge of the shelf. These features represent a very serlous hazard to any sea floor construction.

Near surface faults wore mapped in four main partg of the northern Gulf of Alaska ocs reglon: (1) south of Cape Yakataga, (2) on or adjacent to the Rayak Island Platform, (3) on Tarr Bank, and (4) near Middleton Island. Most of these faults cut Tertiary marine sedimentary 
rocks, along several faultg the sea floor was offset from 5 to $20 \mathrm{~m}$. A few of the faults may cut Holocene sediments, but none of these showed offset at the sea floor.

Preliminary interpretation of the medium-regolution selsmic reflection proflles indicates that the northeastern Gulf of Alaska is structurally complex and consists of geveral areas with markedly differing structural styles. Complexity in the near surface section appears to increase from east to west. Between Icy Bay and Kayak Island the shelf is underlain by two type of structures. The first type is a series of asymmetric linear folds that trend obliquely across the shelf, roughly between northeast-southwest and east-west. The second type of structure is a large shelf-edge arch, east of Kayak Island, trending subparallel to the coast and having a very gentle surface dip.

The shelf between Rayak and Middleton Island is underlain by a broad zone of coraplex structures trending between east-west and northeast southwest, subparallel to major onland structures and to the eastern Aleutian Trench. Structural highs tend to be asymetric and bounded by thrust faults on thelr south or southeast limbs. Oplift, deformation and fauling are greater than on the Icy Bay structural features, and the crests of many of the highs appear to have been truncated by erosion, exposing complexly deformed Tertiary rocks at or near the sea floor. Northwest of Middleton Island are two large northwest trending structural highs separated by a deep basin. 
Bruns, T, $R_{1}$ and Plafker, George, 1975, Preliminary structural map of part of the offshore Gulf of Alaska Tertiary. Province, U. S. Geol. Survey open-file report $75-508$.

Bruns, T. R. and Plafker, George, 1975, Preliminary results of a 1974 geophysical study of the offshore'Gulf of Alaska Tertiary Province (abs): Pacific sections Am: Assoc. Petroleum Geologists ana Soc. Econ. Paleontologists and Mineralogists Joint Ann. Mtg., Long Beach, California, April, 1975, abs. with program, p. 32.

Carlson, P. R., Bruns, T. R., and Molnia, B. F., 1975, Submarine slides and nearsurface faults northern Gulf of Alaska: U.S. Geol. Survey open-flle report $75-504$.

Carlson, P. R. and Molni'a, B. F, 2975a, Massive submarine slide in the Gulf of Alaska: Geol. Soc. America Abstracts with Programs, v. 7, no. 7, p. 1018 .

Carlson, P. R. and Molnia, B. F., 1975b, Preliminary isopach map of Holocene sediments, northern Gulf of Alaska: U.S. Geol. Survey open file report no: $75-507,8 \mathrm{p}$.

Carlson, P. R., Molnia, B. F. and Reimnitz, Erk, ịn press, Disposal, distribution, and thickness of Holocene sediment on the continental shelf, northern Gulf of Alaska, Am. Assoc. Petroleum Geol., Pacific Section.

Coulter, H. W. and Migliaccio, R. R., 1966, Effects of the earthquake of March 27, 1964, at Valdez, Alaska: U.S. Geol. Survey Prof. Paper $542-c, p \cdot c 1-c 36$.

Grantz, Arthur, Plafker, George, and Kachadoorian, Reuben, 1964, Alaska's Good Friday earthquake, March 27, 1964 - a preliminary geologic evaluation: U.S. Geol. Survey Circ. 491,35 p. 
Hein, J. R., Scholl, D. W., and Gutmacher, C., in press. Neogene Clay Minexals of the Far NW Pacific and Southern Bering Sea; Sedimentation and Dtagenesis, in AIPEA Proceedings 1975, International Clay Conference, Mexico City.

Molnia, B. F. and Carlson, P. R., 1975a, Base map of the northern Gulf of Alaska: U.S. Geol. Survey open file report no. 75-506, 1 p.

Molnia, B. F., and Carlson, P. R., 1975b, Surface sediment distribution map northern Gulf of Alaska: U.5. Geol. Survey openfile report $75-505$.

Morgenstern, N. R., 1967, Submarine slumping and the initiation of turbidity currents in Richards, A. F., Marine geatechniques: Chicago, U. of Illinois Pxess, 327 p.

Plafker, George, 1967, Geologic map of the Gulf of Alaska Tertiary Province, Alaska: U.S. Geol. Survey MIsc. Geol. Inv. Map I-484, scale $1: 500,000$

Plafker, George, 1969, Tectonics of the March 27, 1964, Alaskan Earthquake: U.S. Geol. Survey Prof. Paper 543-I, 74 p. Plafker, George, 1971, Pacific margln Tertiary basin, in Future petroleum provinces of North America: Am. Assoc. Petroleum Geologists Mem. 15, p. 120-135.

Plafker, Geroge, 1974, Preliminary geologic map of Kayak and Wingham Islands, Alaska: U.S. Geol. Survey open-file map 74-82. 
Plafker, George, Kachadoorian, Reuben, Eckel, E. B,, and Mayo, L. R., 1969, Effects of the earthquake of March 27, 1964, on various communities: U.5. Geol. Survey Prof. Paper 542-G, 50 p. Reimnitz, Brk, 1966, Late Quaternary history and sedimentation of the Copper River detla and vicinity, Alaska (unpublished Ph.D. dissertation, La Jolla: California Univ., San Diego, 160 p. Reimnitz, Erk, 1972, Effects in the Copper River Delta, in, The great Alaska earthquake of 1964: Oceanography and Coastal Engineexing: Washington, D.C., Natl. Academy of Sciences, p. 290-302.

Reimnitz, Exk, and Carlson, P. R., 1975, Circulation of nearshore surface water in the Gulf of Alaska, in Carlson, P. R., Conomos, T. J., Janda, R. J., and Peterson, D. H., Principal sources and dispersal patterns of suspended particulate matter in nearshore surface waters of the northeast Pacific Ocean: ERTS final report, Natl. Tech Info. Service E75-10266, 136 p.

von Huene, Roland, Molnia, B. F., Bruns, T. R., and Carlson, Q. R., 1975, Seismic profiles of the offshore Gulf of Alaska Tertiary Province, R/V Thompson sept - Oct., 1974: U.S. Geol. Survey Open File report $75-664$.

Walkex, D. A., Linton, A. E., and Schafer, C. T., 1974, Sudan-Black B; a superior stain to Rose Bengal for distinguishing living from non-living foraminifera: Jour. Foram. Research, v. 4, no. 4 , p. 205-215.

winkler, G. R., 1973, Geologic map of the Cordova A-7, A-8, B-6, B-7, and B-8 quadrangles (Hinchinbrook Island) Alaska: U.S. Geol. Survey Misc. Field Studies Map MF-531. 

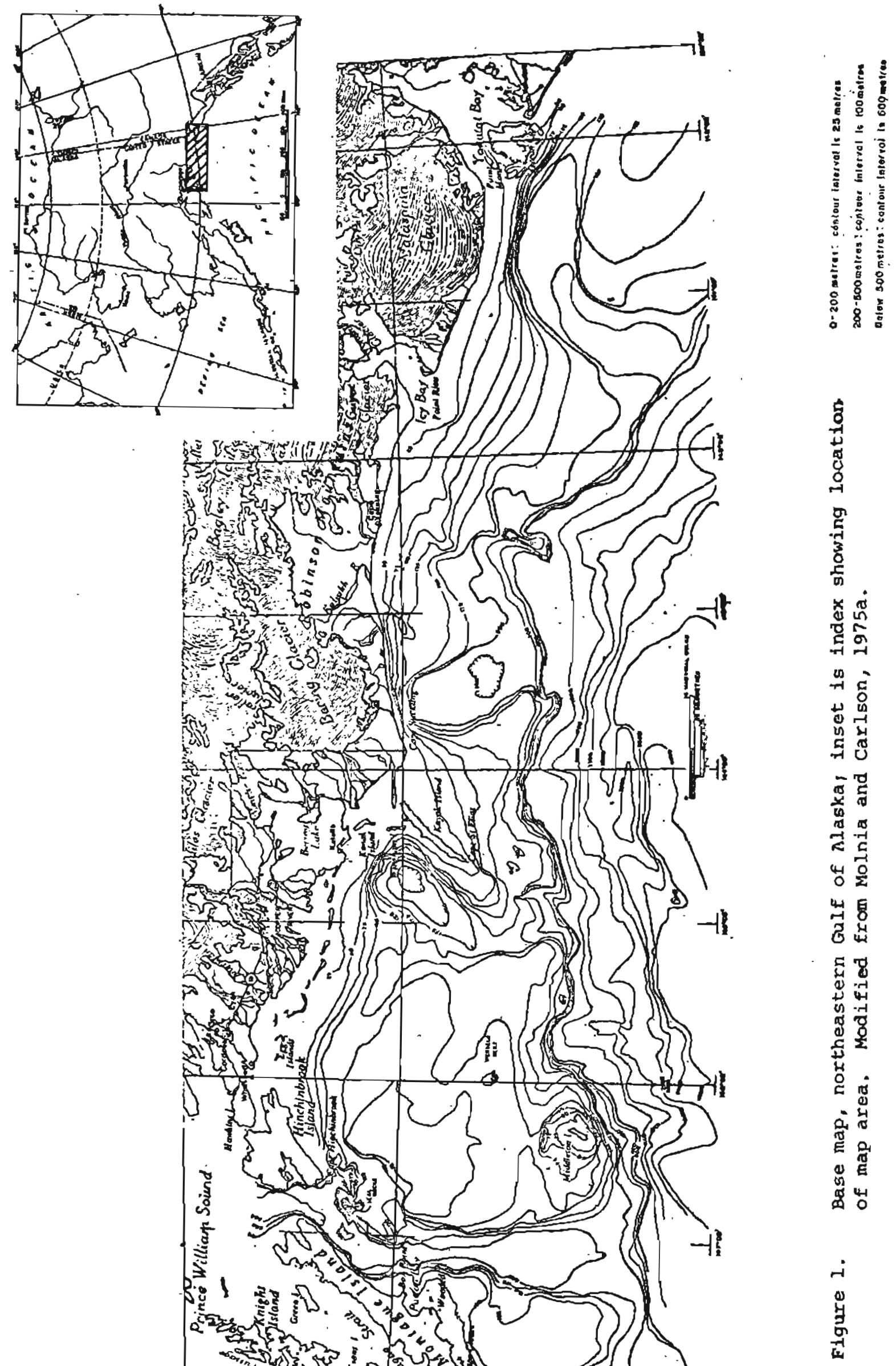


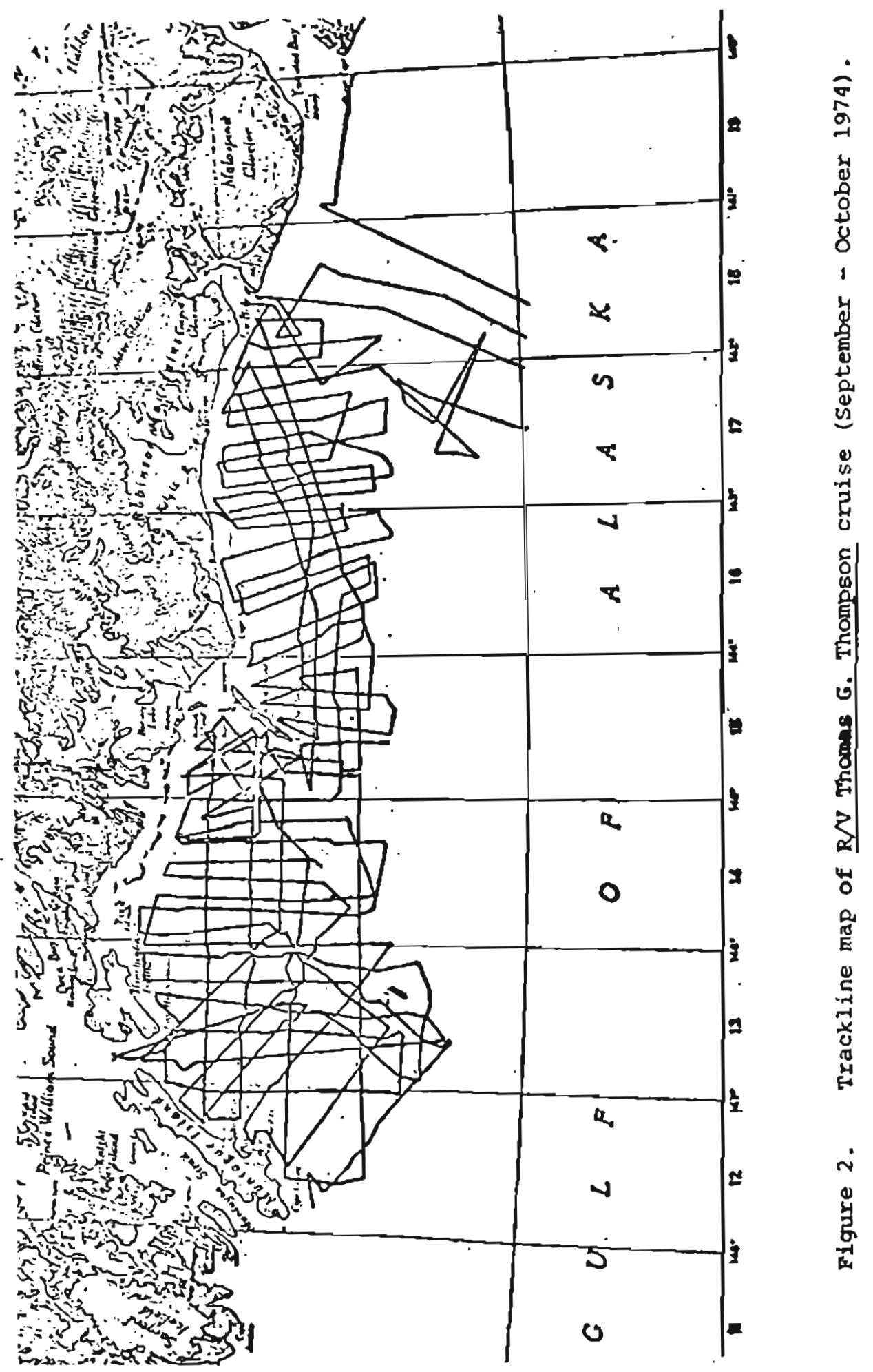




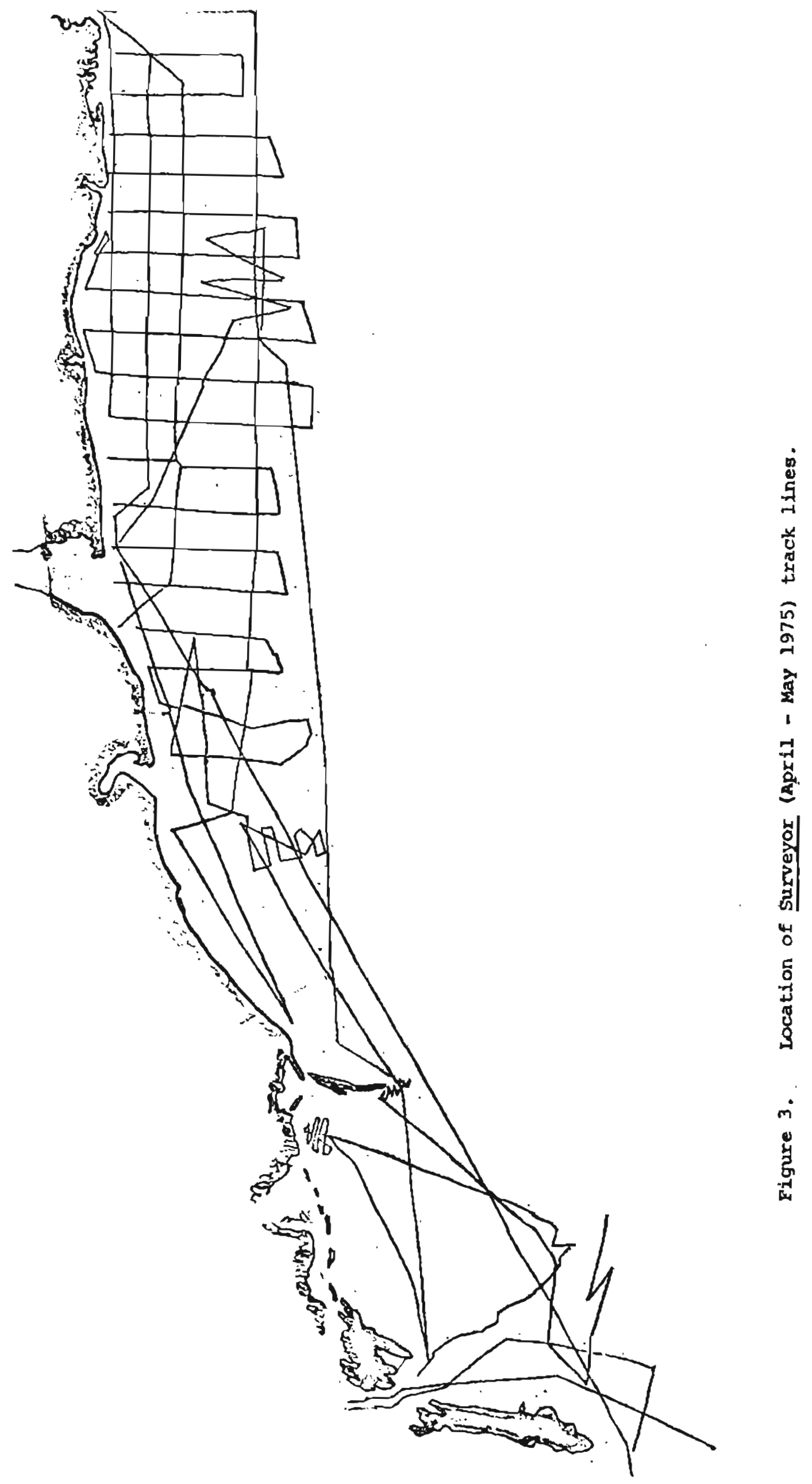




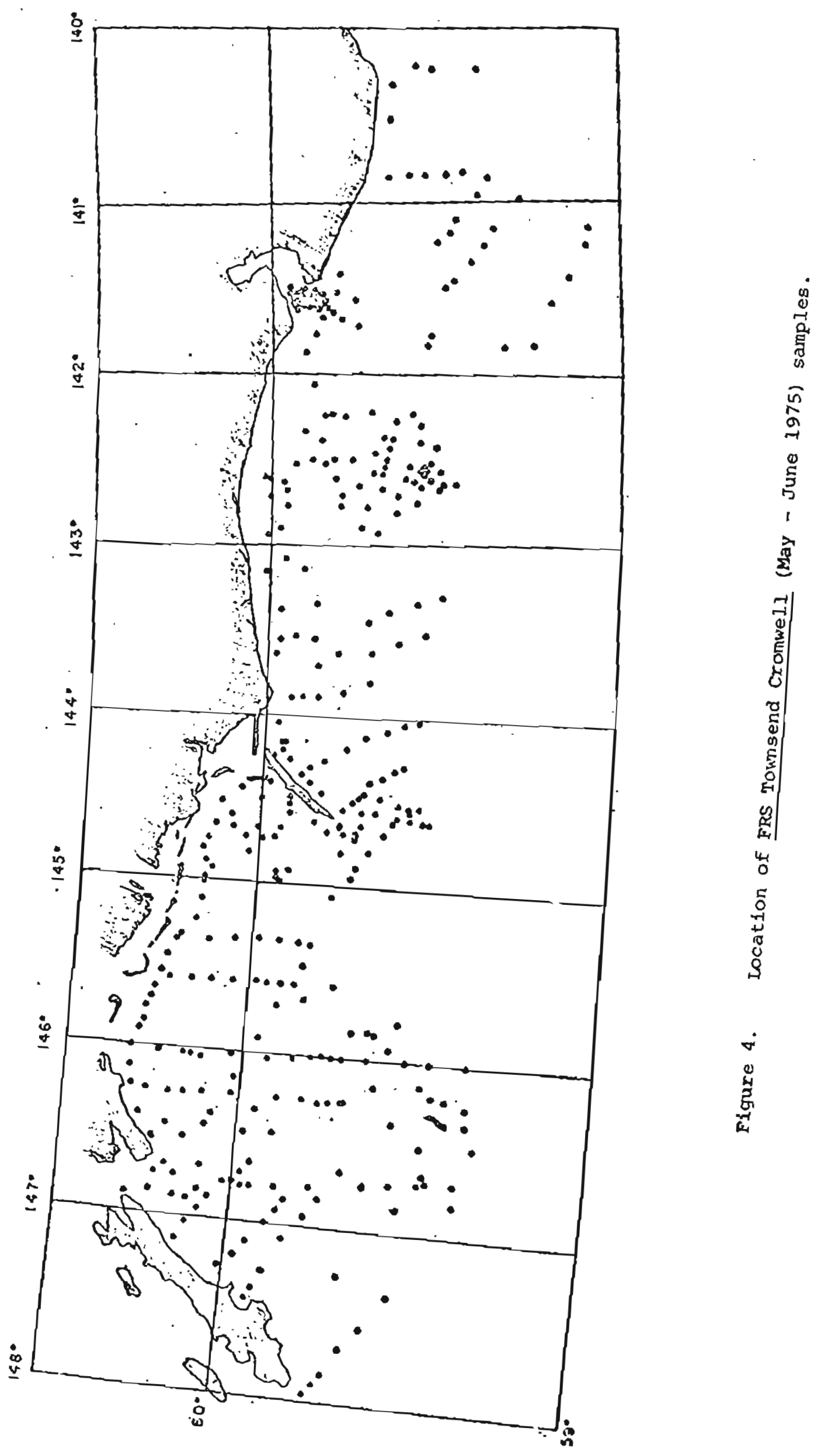




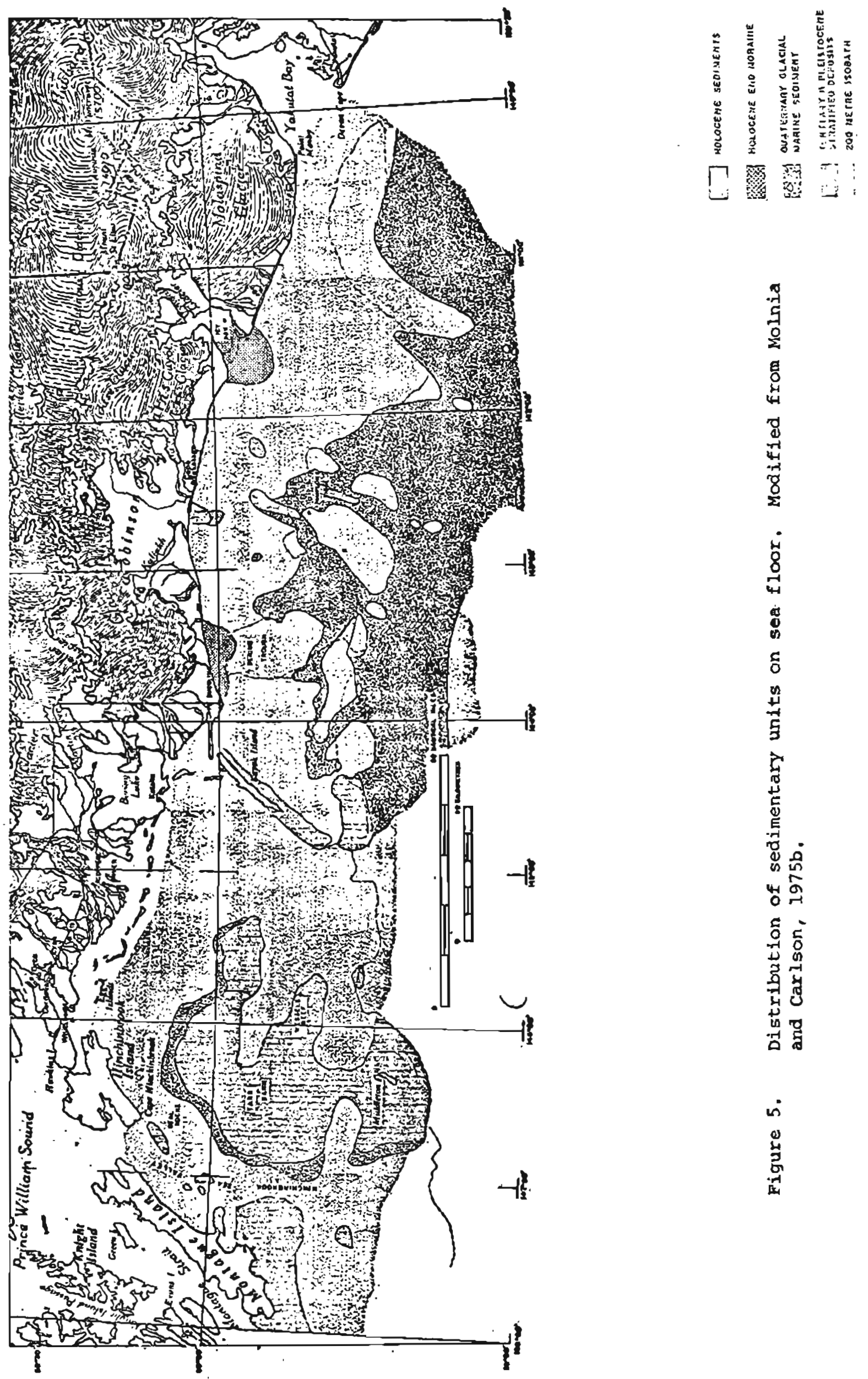




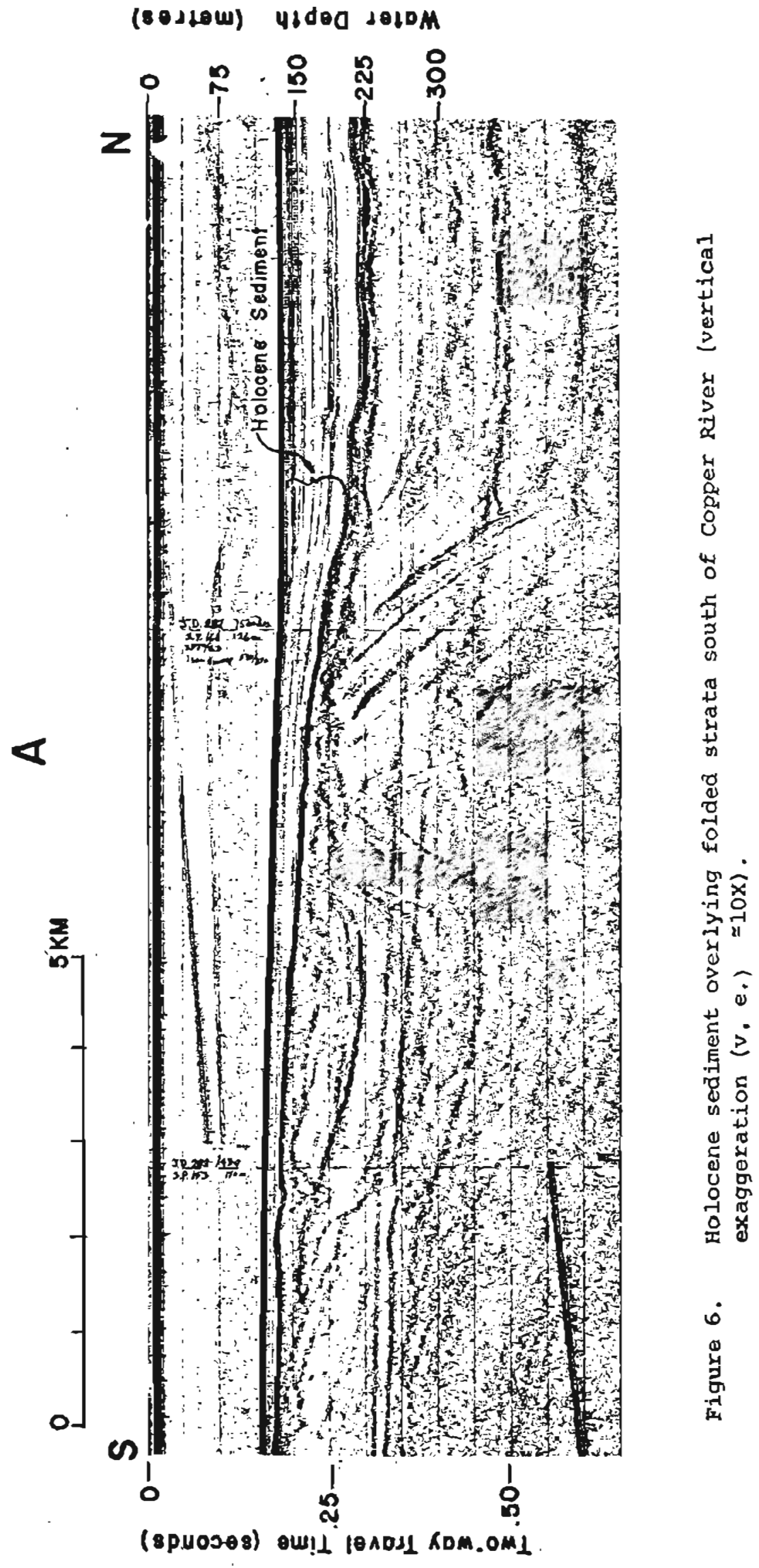




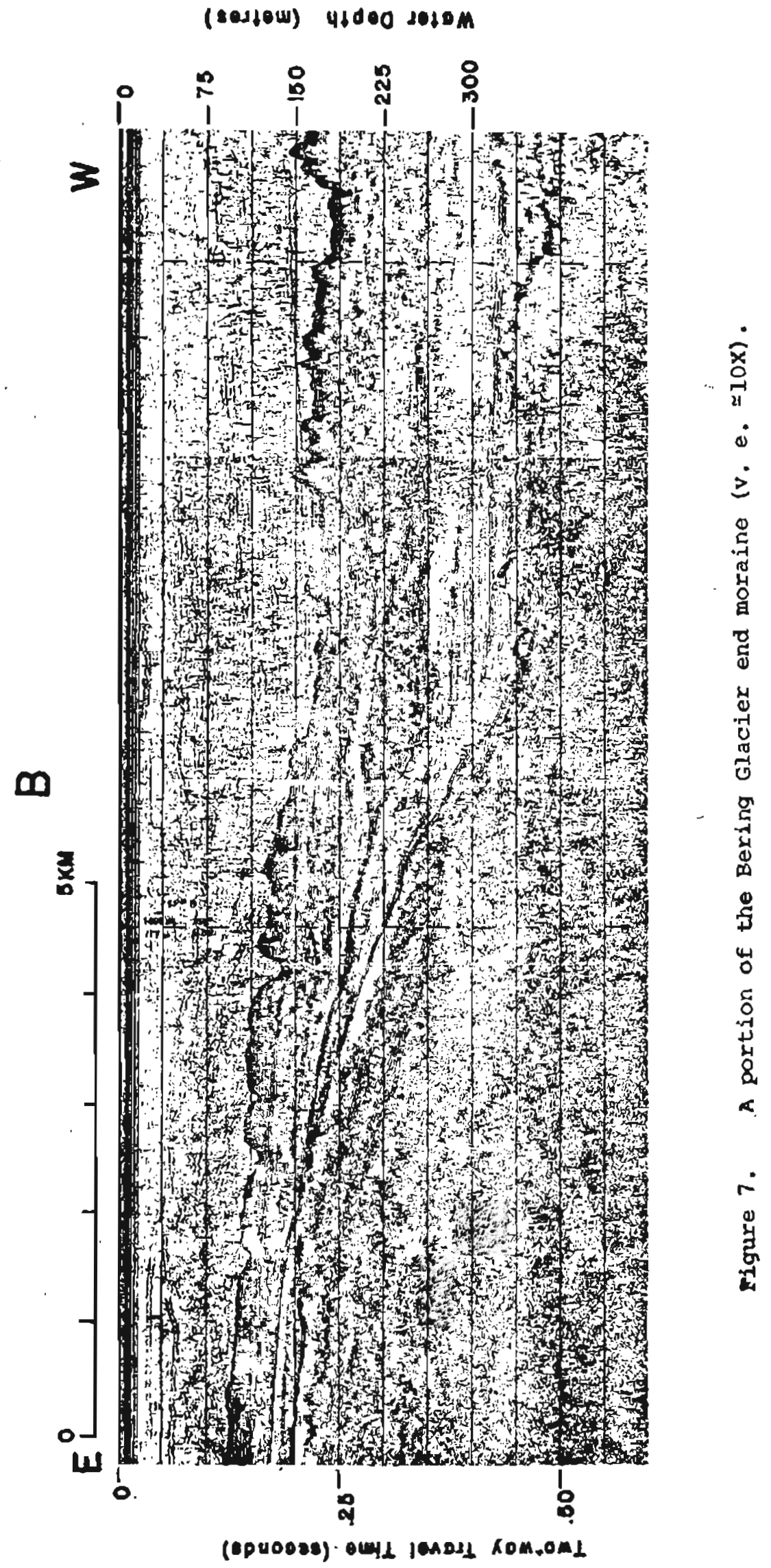




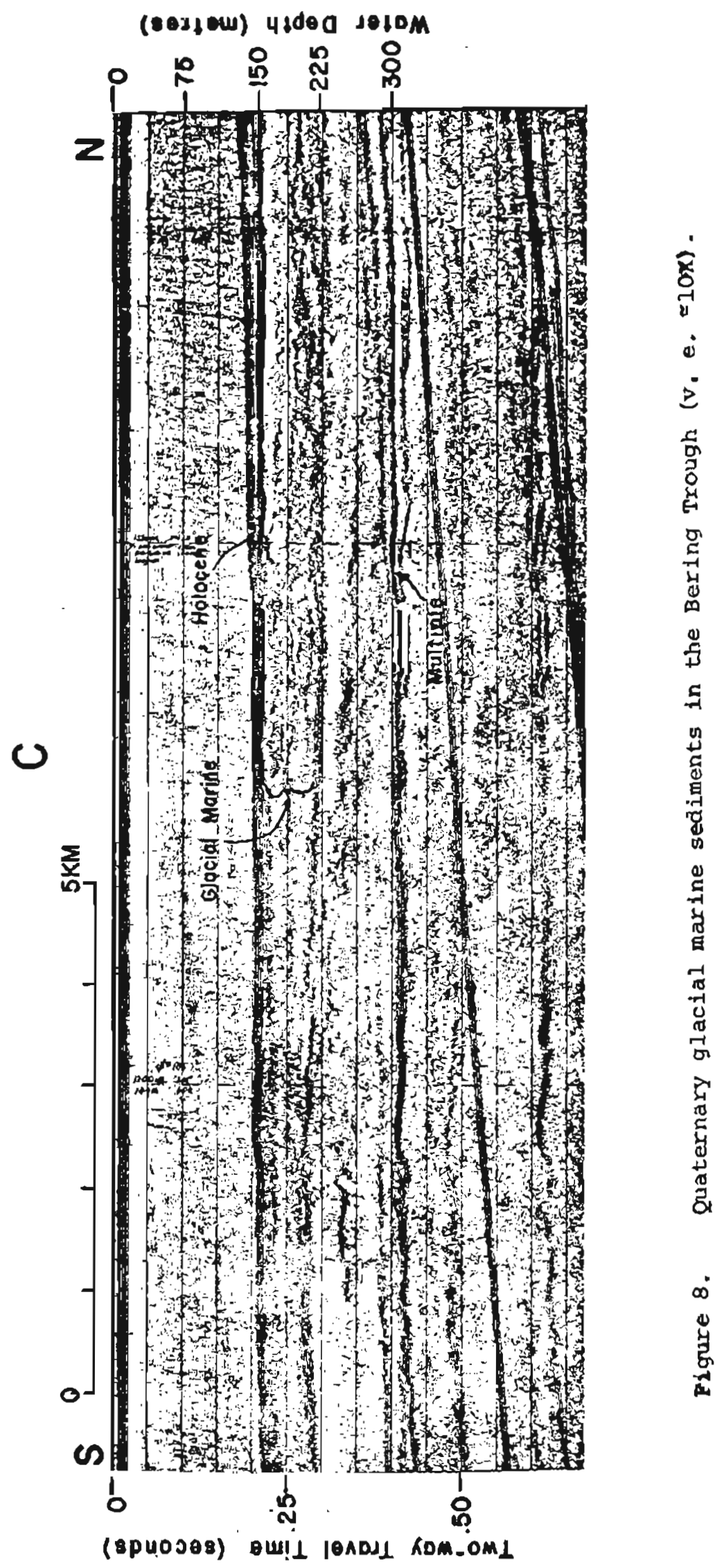




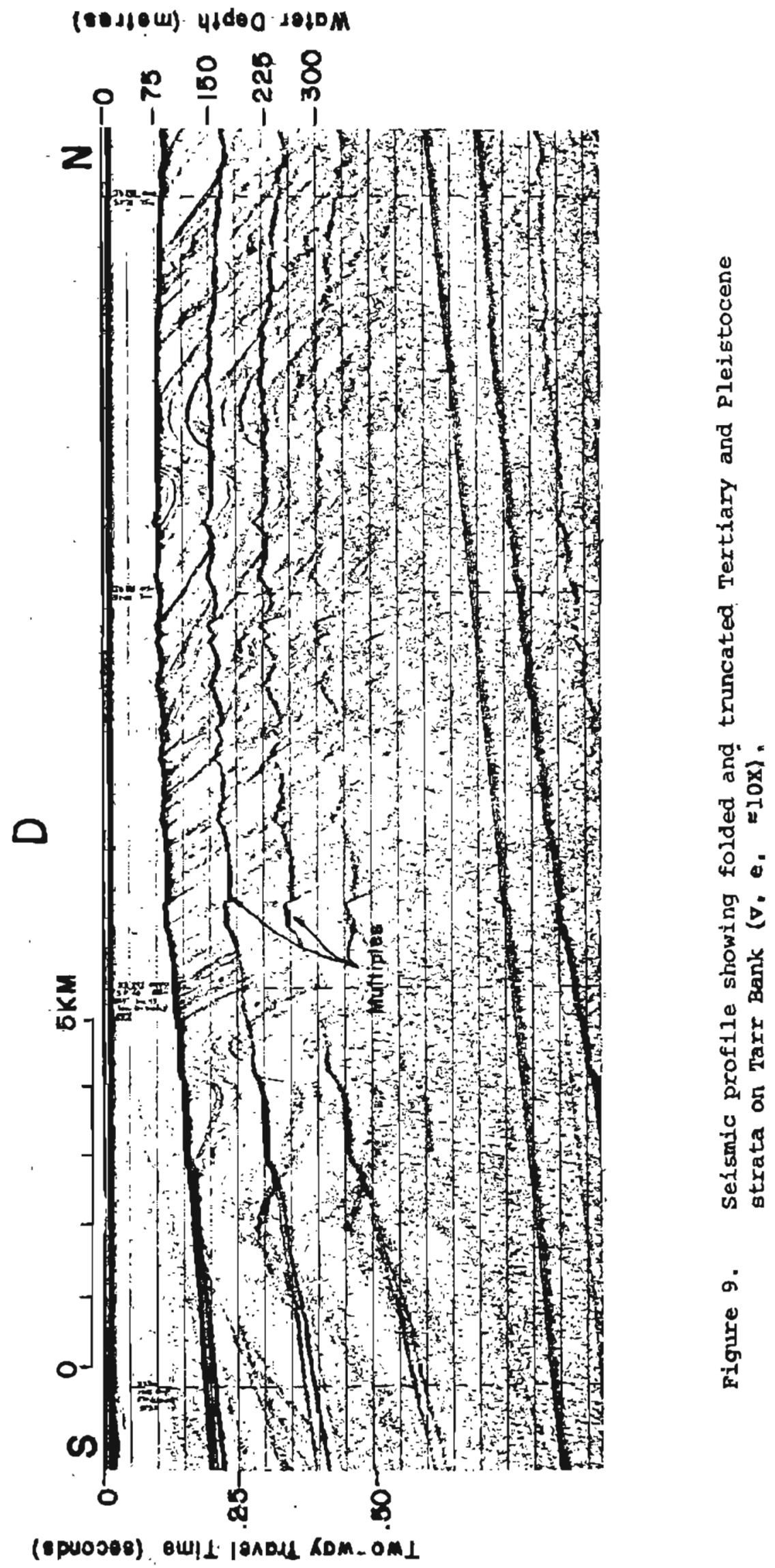




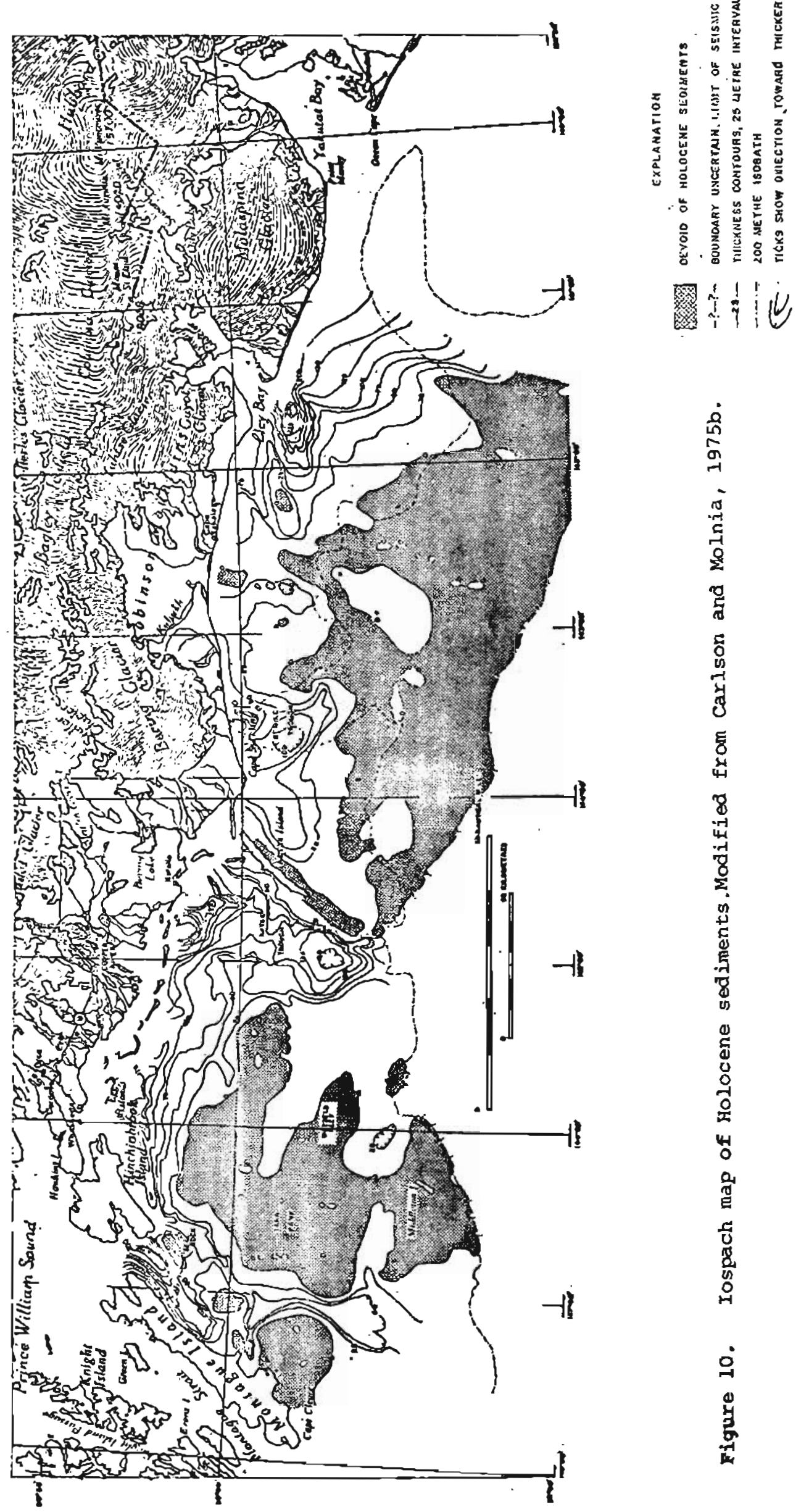




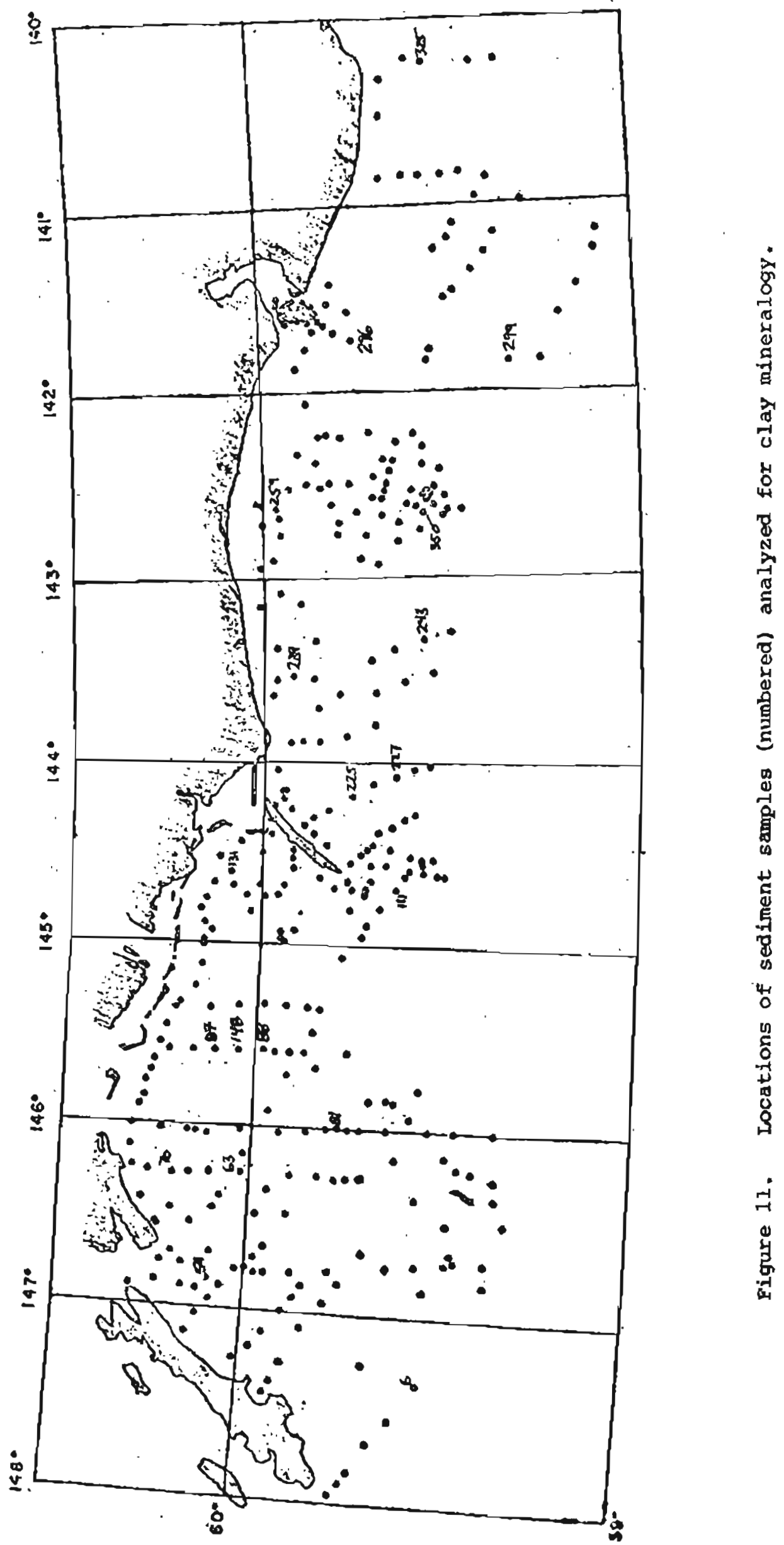




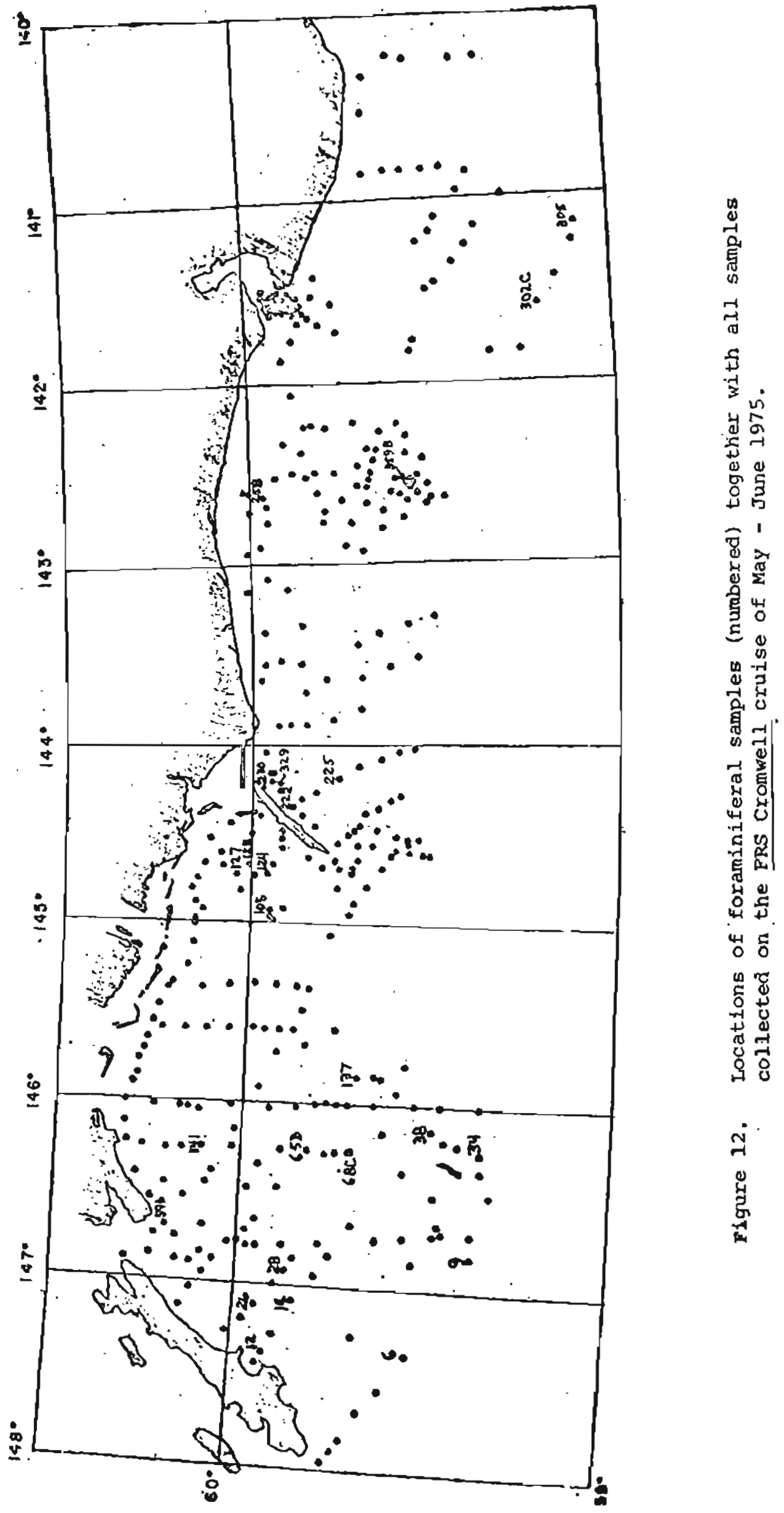




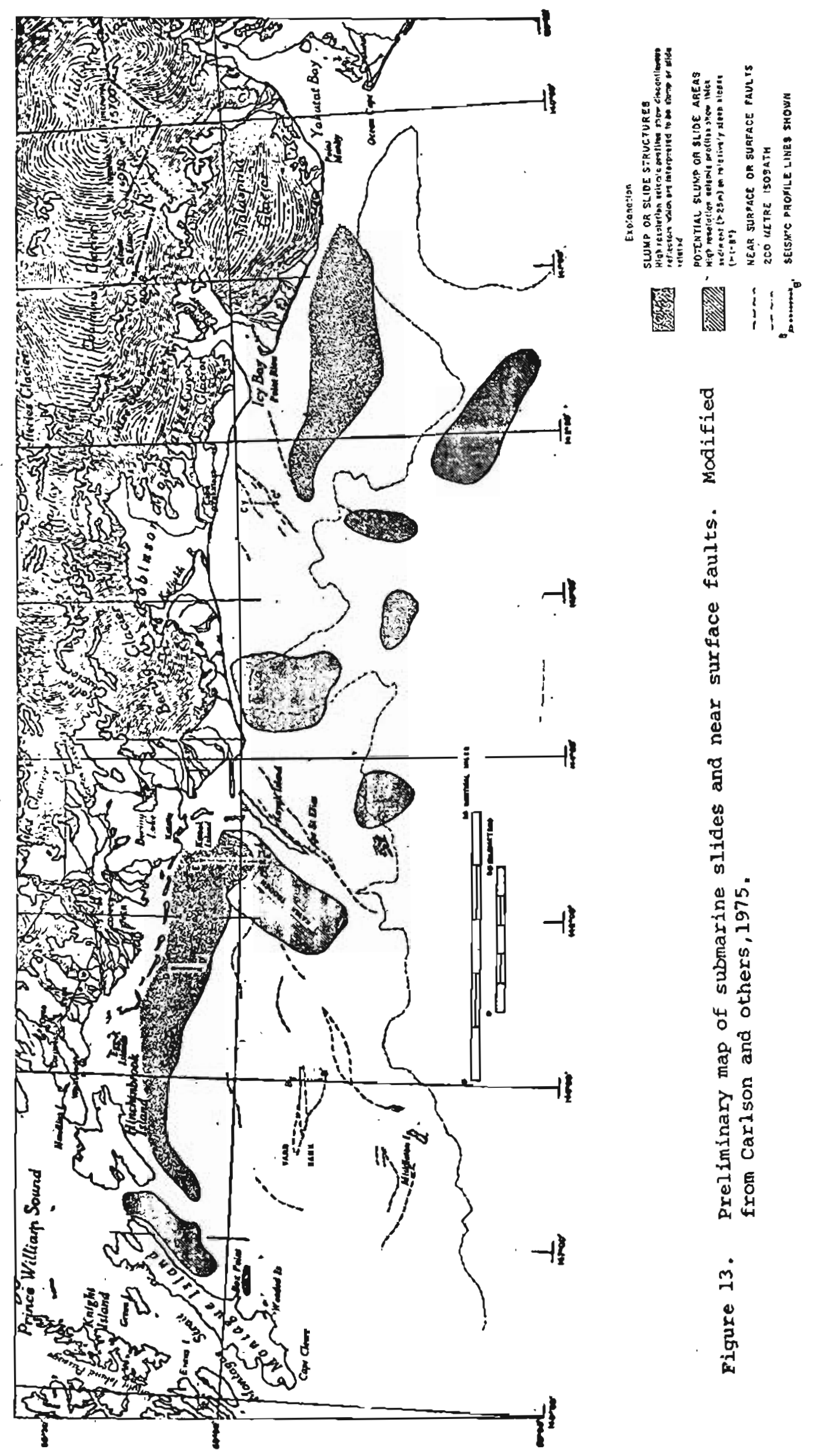




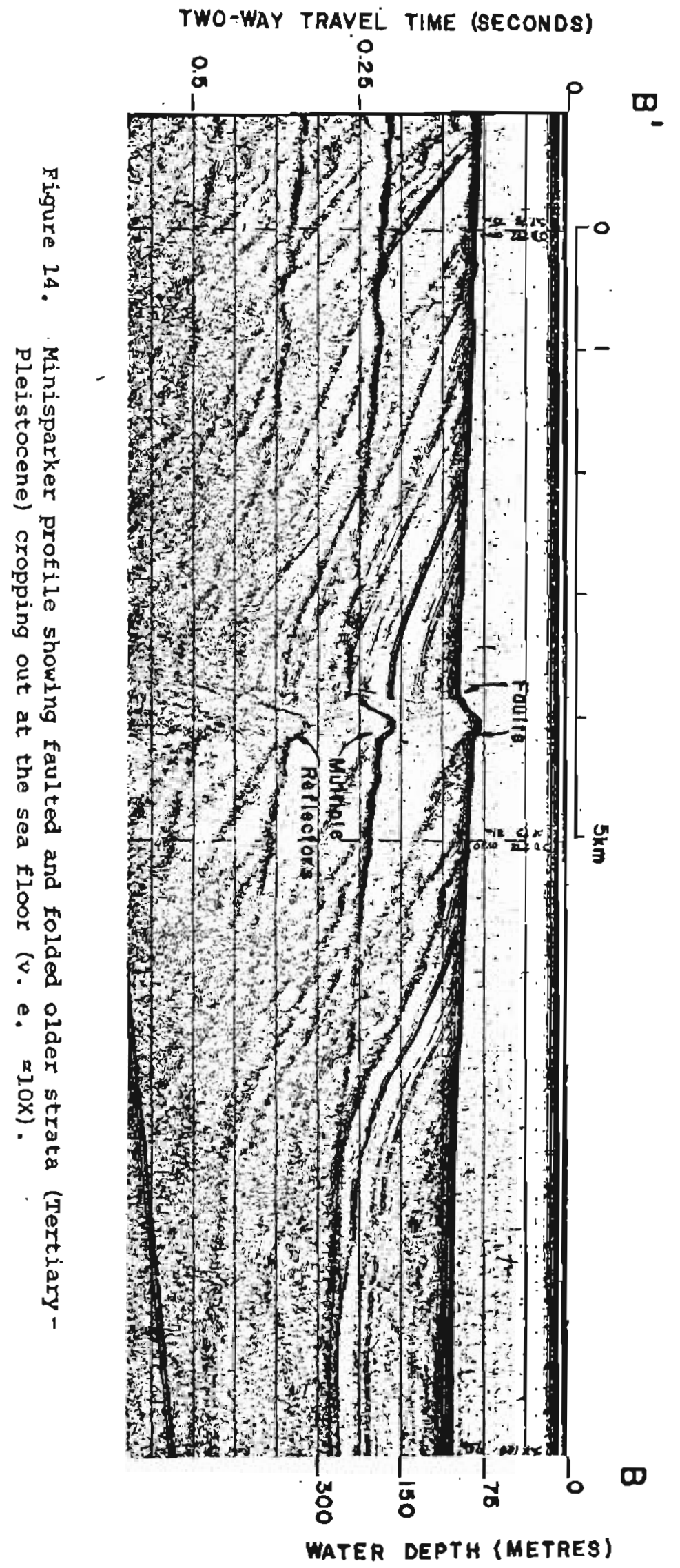




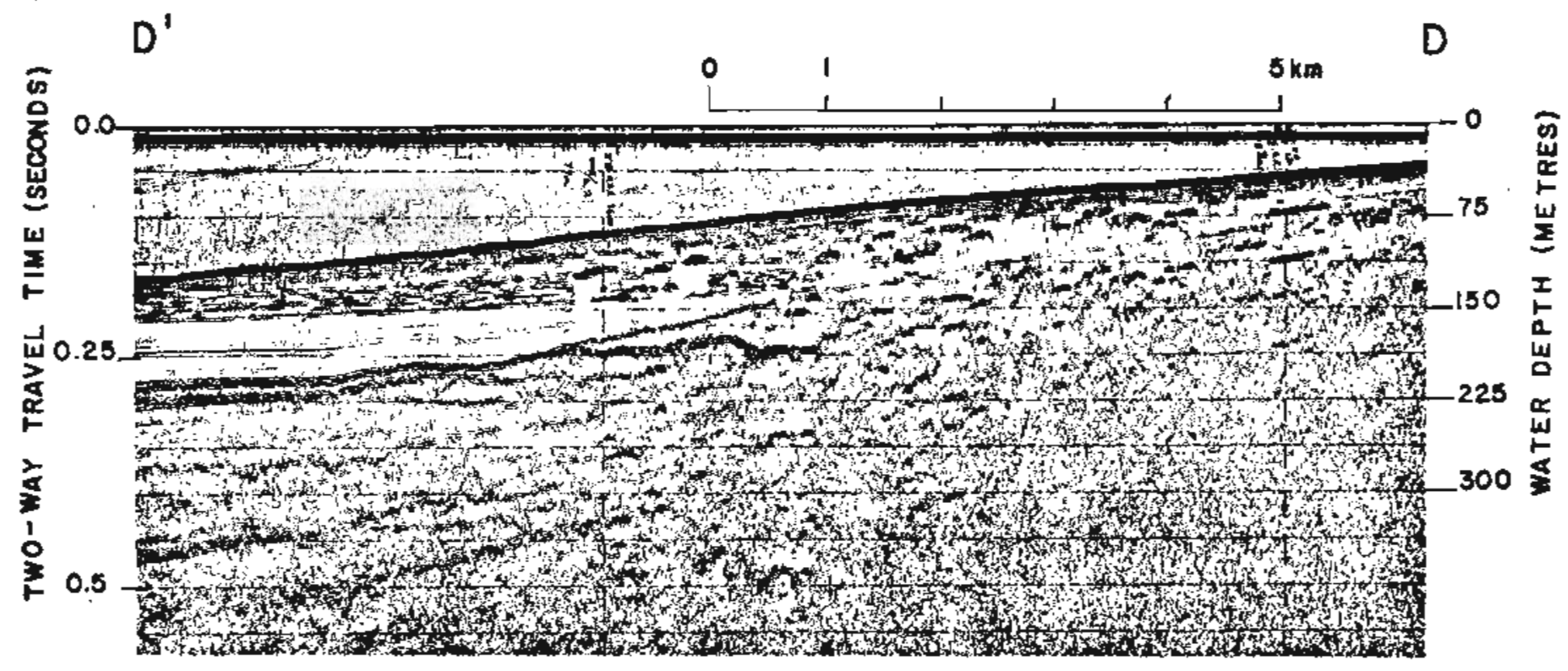

Figure 16. Minisparker profile showing disxupted reflectors of slump structures (left $1 / 3$ ) and gas-charged sediments (right 2/3) in copper River prodelta sediments $(v, e,=10 \mathrm{X})$. 


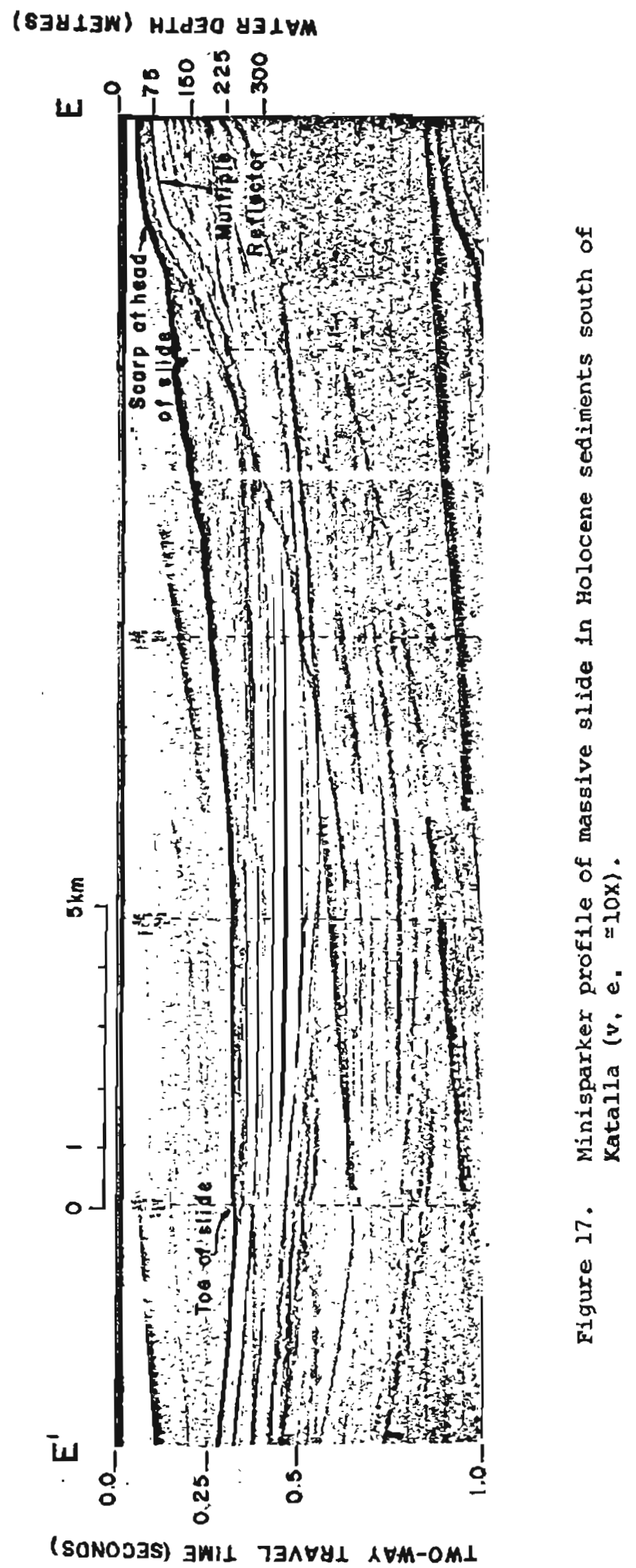




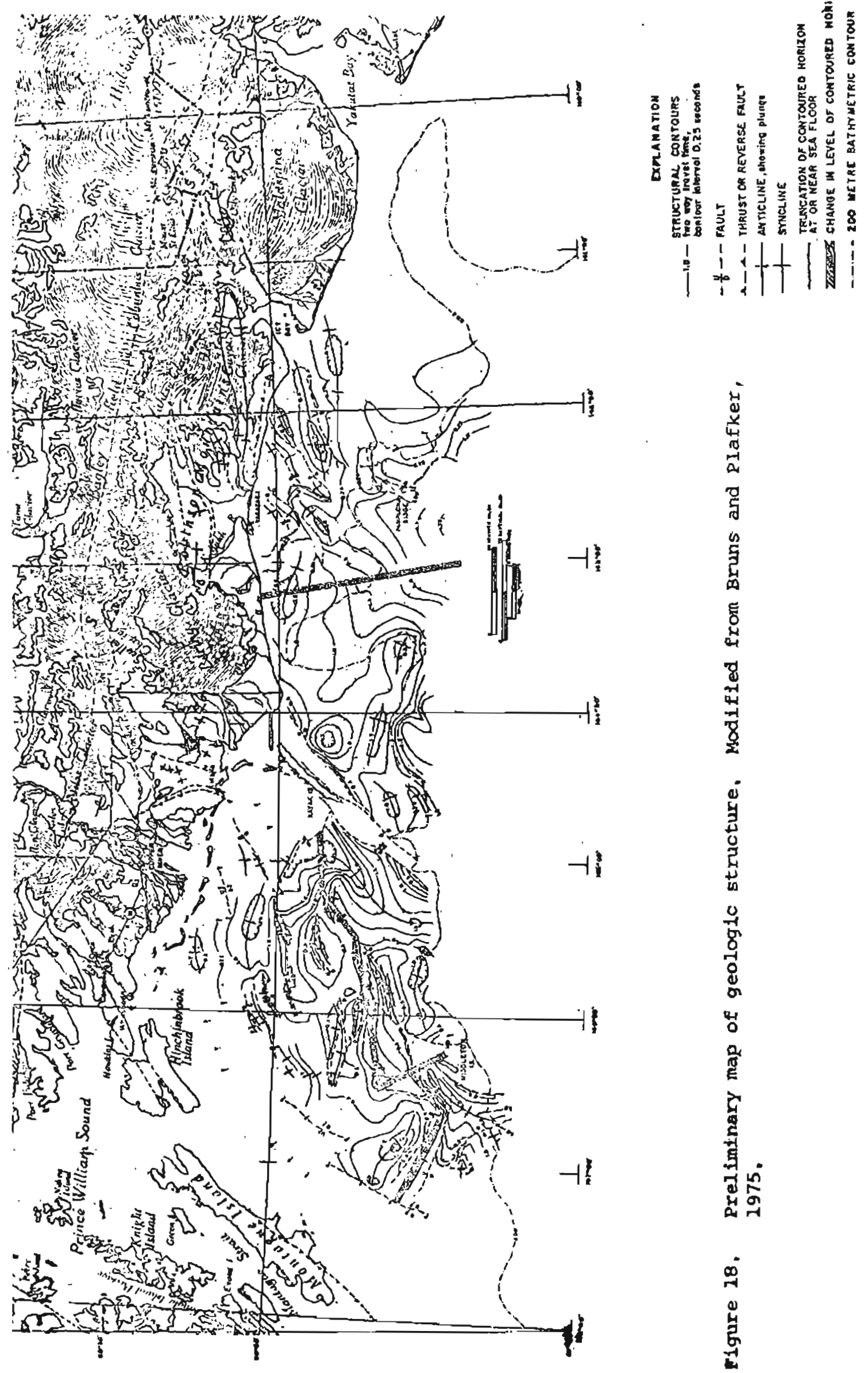

